\title{
Helicopter-borne radar imaging of snow cover on and around glaciers in Alaska
}

\author{
Alessio GUSMEROLI, ${ }^{1}$ Gabriel J. WOLKEN, ${ }^{2}$ Anthony A. ARENDT ${ }^{3}$ \\ ${ }^{1}$ International Arctic Research Center, University of Alaska Fairbanks, Fairbanks, AK, USA \\ E-mail: agusmeroli@alaska.edu \\ ${ }^{2}$ Alaska Division of Geological \& Geophysical Surveys, Fairbanks, AK, USA \\ ${ }^{3}$ Geophysical Institute, University of Alaska Fairbanks, Fairbanks, AK, USA
}

\begin{abstract}
During spring 2013, we performed $500 \mathrm{MHz}$, helicopter-borne impulsive ground-penetrating radar surveys of several glaciers and glacier forelands in south-central Alaska, USA. These surveys were designed to obtain spatially distributed measurements of snow accumulation spanning a broad range of continental and maritime climatic zones. Visual assessment of radar images shows that data quality varied with the terrains and was optimal for snow that covered smooth glacier ice and firn, smooth debris-covered areas and moraines, freshwater lake and river ice, tundra, and taiga. Conversely, returns from the base of the snowpack were unrecognizable over rough debris-covered glacier termini, icefalls and some high-altitude accumulation basins. Optimal flying speed was $15-20 \mathrm{~m} \mathrm{~s}^{-1}$ (30-40 kt). At these speeds, which are two to three times faster than previously reported for such surveys, we could still identify snow-depth data with confidence, at a point spacing of $\sim 1.5-2.0 \mathrm{~m}$. Data quality on glaciers decreased with increased air speed, though useful echoes from the base of the snowpack were still obtained at $40-45 \mathrm{~m} \mathrm{~s}^{-1}$ (87 kt; data point spacing of 6-8 m). Similar high-speed surveys over nonglacial terrains were unsuccessful, as basal reflections were no longer recognizable.
\end{abstract}

KEYWORDS: accumulation, aerogeophysical measurements, ground-penetrating radar, mountain glaciers, snow

\section{INTRODUCTION}

The assessment of snow cover over large, mountainous, glacierized watersheds is challenging and time-consuming. Traditional measurements rely on manual snow-probing and snow-pit analysis. In some regions automated stations provide snow depth observations by weighing the mass of snow accumulated, or by using ranging devices to determine variations in snow height. These automated observations often do not provide sufficient sampling density to assess snow depth patterns over large regions. Passive microwave remote sensing provides snow water equivalence measurements over broad regions (Liu and others, 2014), but is unable to resolve changes at the scale of individual watersheds because of its coarse spatial resolution and the fact that large errors can occur whenever liquid water is present in the snowpack, as is often the case in Alaska. Even in the best-case scenario, a research team lands from place to place, aided by helicopter support, and obtains only a handful of estimates of snow depth and snow water equivalence. The resulting data may or may not represent important characteristics of snow distribution and snow depth variance.

Continuous helicopter-borne radar sounding of snow depth is a promising approach for assessing snow depth variations over large regions (Venier and Cross, 1972; Holmgren and others, 1998; Marchand and others, 2003; Yankielun and others, 2004; Machguth and others, 2006). A number of studies have used non-commercial radar over alpine prairies (Yankielun and others, 2004; Marshall and others, 2008) or sea ice (Panzer and others, 2013). Meanwhile, helicopter-borne ground-penetrating radar (GPR) studies of mountain glaciers have typically dealt with documenting the spatial variability of snow (Machguth and others, 2006), deriving firn properties (Arcone, 2002), detecting englacial conduits (Arcone and Yankielun, 2000) or investigating glacier thermal structure (Ryser and others, 2013). To date, there has been little emphasis on intercomparison of GPR snow-cover images acquired over different terrains.

Many questions regarding the capabilities of helicopterborne GPR snow sounding in mountainous areas are still unanswered. For example, it is unclear how the system performs over various terrains including maritime zones with thick seasonal snow $(>2 \mathrm{~m})$, debris-covered zones, areas with large moraines, crevassed areas, large accumulation basins, and proglacial areas.

The purpose of this paper is to assess the performance of a commercially available helicopter-borne $500 \mathrm{MHz}$ GPR system for imaging the snowpack in and around glacierized areas of Alaska. Our main goal is to understand the potential of this technique over a variety of terrains, identifying zones in which the technique works well and zones in which it does not work. Emphasis is placed on identifying surface conditions where helicopter-borne GPR surveying produces favorable data for estimating winter snow accumulation, and on detailing the optimal radar settings and flying parameters necessary for future data recovery over these surfaces.

\section{METHODS}

A pair of Sensors \& Software pulseEKKO Pro $500 \mathrm{MHz}$ impulsive GPR transducers were installed and centered underneath a helicopter. These transducers consisted of two $500 \mathrm{MHz}(100 \%$ bandwidth) antennas (one transmitter and one receiver), spaced $0.23 \mathrm{~m}$ apart. Pulse length in air was $\sim 0.6 \mathrm{~m}$, antenna gain was $3 \mathrm{~dB}$, beamwidth was $\sim 87^{\circ}$ and 


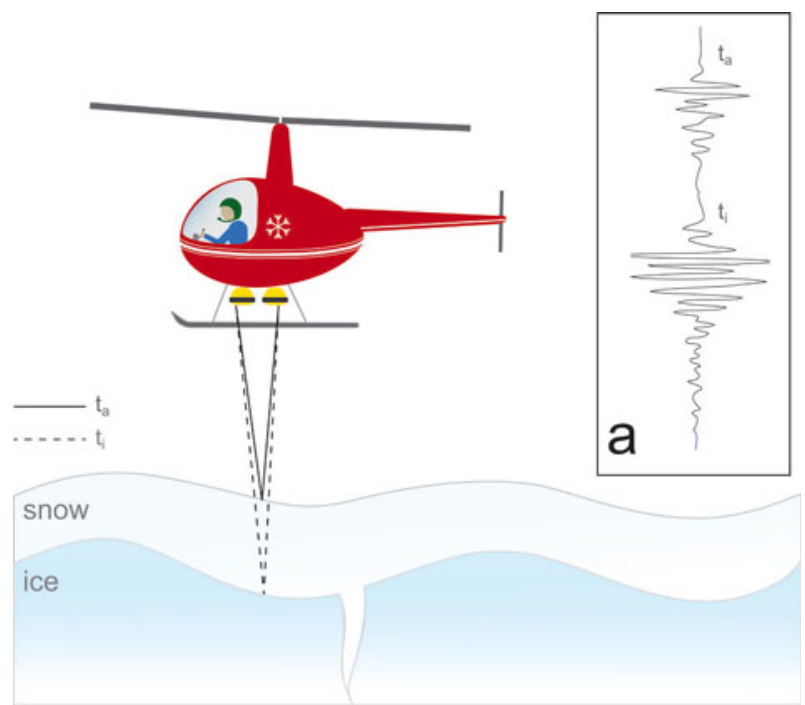

Fig. 1. Helicopter-borne radar surveying of the snow cover on glaciers. The radar transmitter sends electromagnetic pulses down to the snow. The first interface that interacts with the pulse is the boundary between air and snow $\left(t_{\mathrm{s}}\right)$; the second interface is the boundary between snow and ice $\left(t_{\mathrm{i}}\right)$. Both are recorded by the radar system and are typically used to derive snow depth. Inset (a) is a schematic example of a waveform with the two events identified (quantitative examples are provided later in the paper).

$100^{\circ}$ for the $\mathrm{H}$ and $\mathrm{E}$ plane, respectively, pulse repetition frequency was $100 \mathrm{kHz}$ and four stacked traces were collected at each location. The transducers were connected via $2 \mathrm{~m}$ long optical cables to a radar control unit, which was operated from inside the cabin of the helicopter. The antennas, although shielded, recorded a significant amount of noise, likely reflecting off the helicopter. As the position of the antennas relative to the helicopter never changed in the survey, this source of noise was easy to remove. A $230 \mathrm{~ns}$ time window (35.5 one-way range in free space) was used for most of the surveys, but was kept flexible in order to accommodate variable altitude above the surface. The helicopter was flown at an altitude of $5-15 \mathrm{~m}$ above the surface. Rapid variations in altitude were generally avoided; variations of a few meters occurred occasionally in regions of rough topography but did not affect data acquisition. The GPR sampling rate was set to $0.1 \mathrm{~ns}$, and positional information was recorded by direct synchronization with a Topcon GRS-1 antenna and receiver.

Helicopter-borne GPR surveys were undertaken in early spring, prior to melt onset. In helicopter-borne snow surveying, the snow depth, $h_{\mathrm{S}}$, is calculated by determining radar travel time within the snowpack, $t_{\mathrm{S}}=\left(t_{\mathrm{i}}-t_{\mathrm{a}}\right) / 2$, where $t_{\mathrm{i}}$ and $t_{\mathrm{a}}$ are radar returns from the bottom and the top of the snowpack, respectively (Fig. 1). Once $t_{S}$ is estimated, $h_{\mathrm{S}}=t_{\mathrm{S}} v_{\mathrm{S}}$, where $v_{\mathrm{S}}$ is the radar wave speed within the snowpack, which can be either measured on the ground with a common-midpoint survey (Brown and others, 2012; Booth and others, 2013), estimated from measured density (Machguth and others, 2006) or assumed from typical values (Gusmeroli and Grosse, 2012; Gusmeroli and others, 2012, 2013). As this paper focuses on the performance of the radar system and not on $h_{\mathrm{S}}$ determination, throughout our study we assume a constant $v_{\mathrm{S}}=0.23 \mathrm{mns}^{-1}$. Using a typical speeddensity inversion, this value corresponds to a bulk snow density of $360 \mathrm{~kg} \mathrm{~m}^{-3}$ (Tiuri and others, 1984; Kovacs and

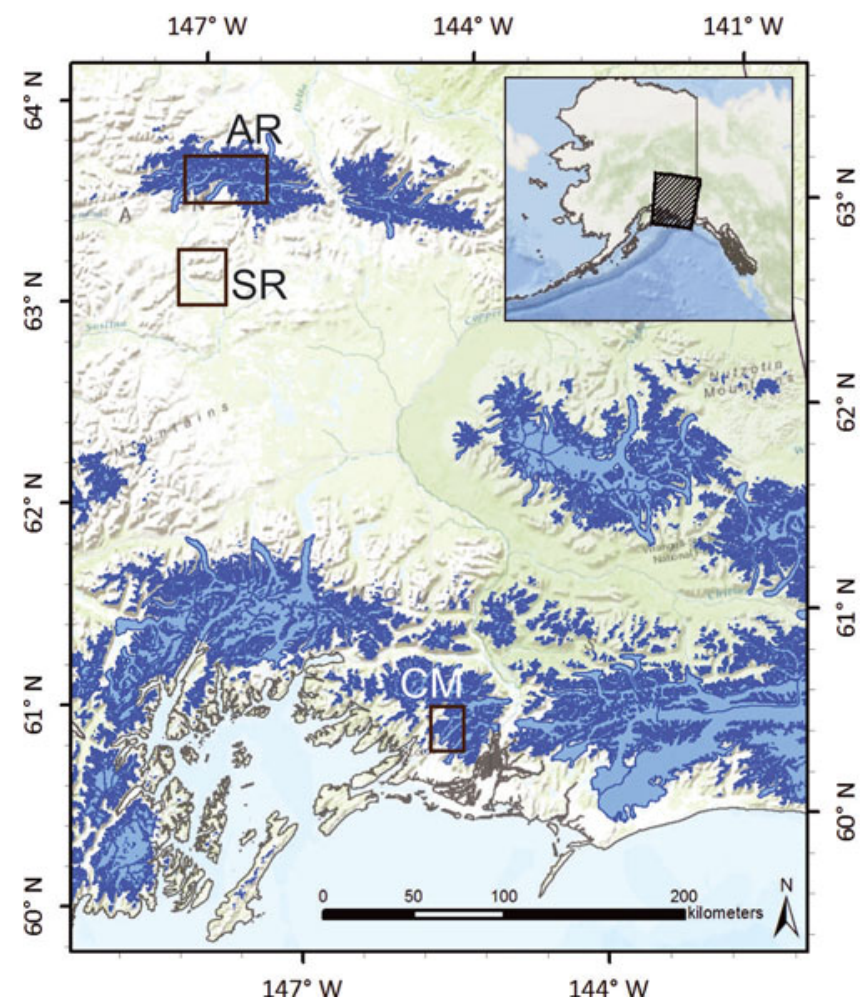

Fig. 2. Study location in south-central Alaska, USA. The Alaska Range (AR), the Susitna River (SR) and the western Chugach Mountains (CM) panels are depicted. Panels are enlarged for details in Figures 3-5. Glacier outlines are from the Randolph Glacier Inventory.

others, 1995). This bulk density agrees with end-of-winter values measured elsewhere in Alaska (e.g. the average of 23 measurements at Wolverine Glacier in March-April 1966-2001 is $390 \mathrm{~kg} \mathrm{~m}^{-3}$ (Mayo and others, 2004)).

Radar data were processed using the commercially available interpretation software Refexw-2D (Sandmeier Software). The processing flow followed standard procedures applied to GPR data (e.g. Daniels, 2004), and included the removal of low-frequency instrument noise (dewow), Ormsby bandpass filtering (corner frequencies 125-250 and $1000-2000 \mathrm{MHz}$ ), correction for spherical divergence, and background noise removal. Radar images (referred to as radargrams or echograms) were produced by displaying the radar data with contrasting colors: blue for positive polarity and black for negative polarity, proportional to radar signal dimensionless amplitudes. White was used to display regions with relatively little radar reflectivity. The strength of a radar return can therefore be judged according to its 'darkness' in the radar images.

\section{STUDY SITES}

In spring 2013, we collected helicopter-borne GPR data over several zones of south-central Alaska (AR in Fig. 2, details in Fig. 3). Data for the Alaska Range glaciers (Fig. 3a) and near the Susitna River (SR in Fig. 2, details in Fig. 3b) were acquired on 15-20 April, whereas data for the western Chugach Mountains (CM in Fig. 2, details in Fig. 3c) were acquired on 17 March. Among the continental glaciers of the Alaska Range (Fig. 3a), surveys focused on West Fork (WF in Fig. 3a) and Susitna (SG in Fig. 3a) Glaciers and were designed to assess the performance of the radar system for 

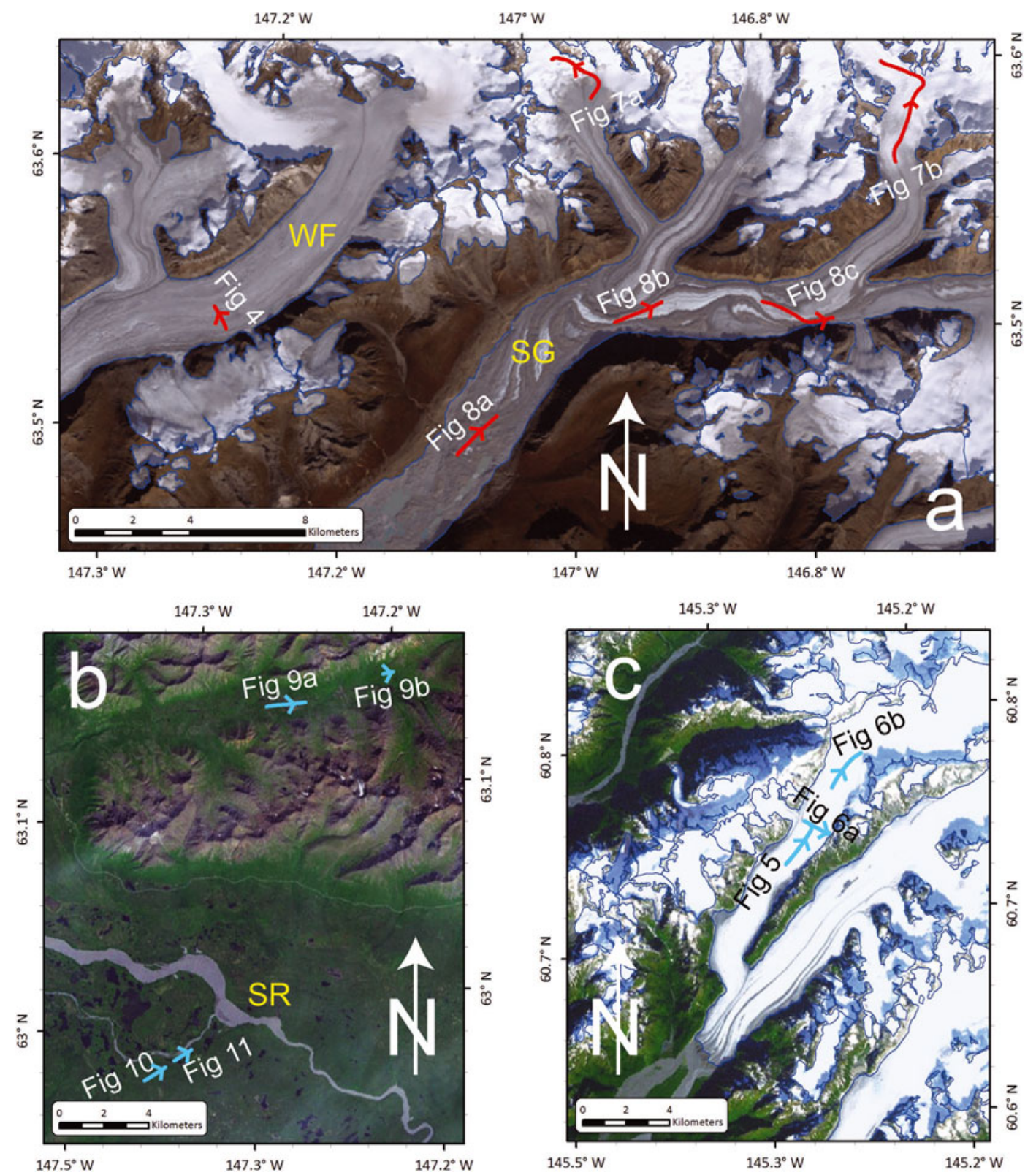

Fig. 3. Helicopter-borne GPR profiles. Blue and red lines show the location of radar images analyzed below. (a) The Alaska Range area with West Fork (WF) and Susitna (SG) Glaciers identified. (b) Susitna River (SR) area. (c) Scott Glacier, western Chugach Mountains. (a) is Landsat Enhanced Thematic Mapper Plus (ETM+) true-color composite (bands 3, 2, 1) from 15 September 2010. (b) and (c) are ESRI World Imagery base layers. Arrows indicate flight direction.

snow that covered glacier ice, meltout debris, moraines and firn in the accumulation area. Near the Susitna River (SR in Fig. 3b), surveys targeted snow that covered taiga and tundra terrains. On the maritime Scott Glacier (Fig. 3c), surveys focused on imaging above and below the equilibrium-line altitude.

\section{RADAR IMAGES FROM DIFFERENT TERRAINS}

The first step in obtaining estimates of snow depth from helicopter-borne radar is to determine both $t_{\mathrm{i}}$ and $t_{\mathrm{a}}$ (Fig. 1) for radar images. The air/snow interface, $t_{i}$, is typically represented by the first reflections noticeable in the radar waveform. The determination of $t_{\mathrm{a}}$, meanwhile, is dictated by the existence of a continuous series of radar reflections caused by the snow/ice (or snow/ground) interface. The radar response to this interface differs according to terrain type. Here we provide our interpretation of a number of examples of radar images from snow-covered on-ice and office terrains. Radargrams were not corrected for altitudinal variations of the helicopter occurring during flight.

\section{Ablation area of glaciers}

The ablation area snow cover of West Fork Glacier in the continental Alaska Range is depicted in Figure 4 (location in Fig. 3a). Returns from the base of the snowpack are clearly identifiable, and the inferred snow depth in this zone was $\sim 1-2 \mathrm{~m}$. The radar survey crossed a large crevasse, visible in the image. In the crevasse, we can observe clear returns from the base of the snowpack. Good-quality data were also found over a thick maritime snowpack, typical of glaciers in the coastal mountains of Alaska. Figure 5 shows an example from Scott Glacier, from an elevation of 740-820 m a.s.I. (location in Fig. 3c). In spite of the generally thick snowpack (>3 m), the reflections are recognizable. Snow depth data interpreted from the surveys at Scott Glacier (Fig. 3c) are shown in 


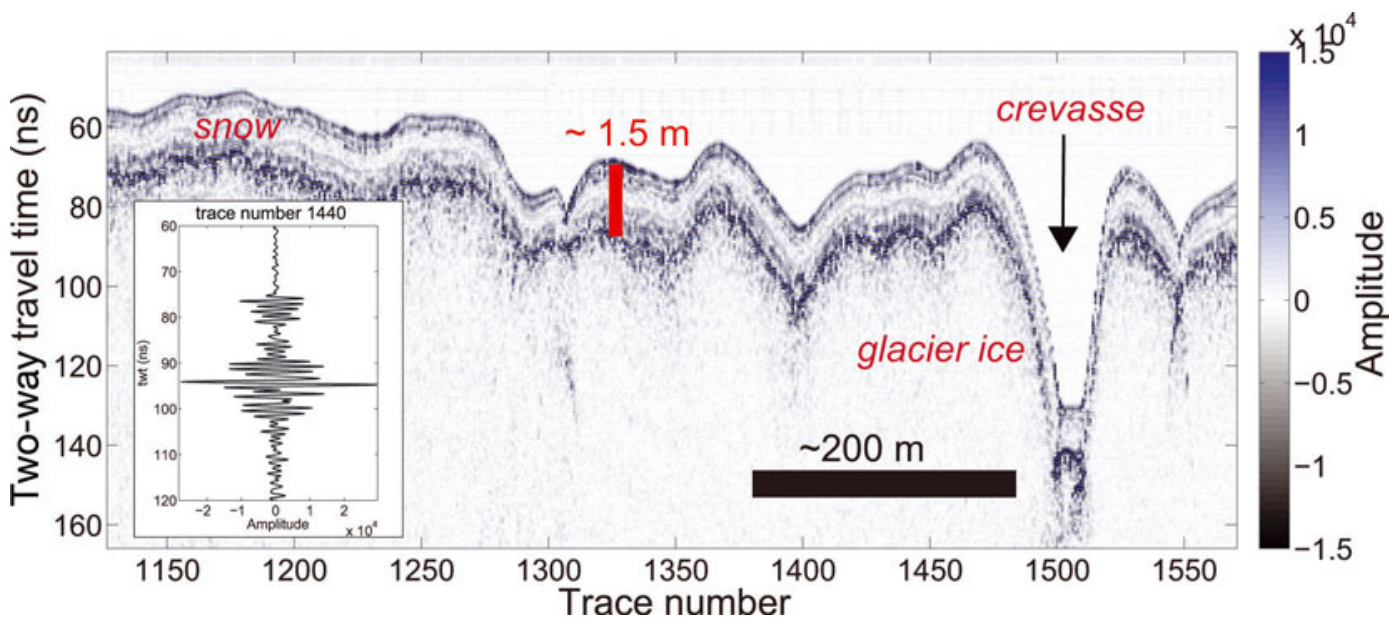

Fig. 4. $500 \mathrm{MHz}$, helicopter-borne GPR image on West Fork Glacier in the Alaska Range (location in Fig. 3a). The snowpack imaged is continental. Data were acquired with a measurement every $\sim 2 \mathrm{~m}$. Depth scale in the snowpack is for guidance only and was derived using radar velocity of $0.23 \mathrm{~m} \mathrm{~ns}^{-1}$. Inset shows sample radar trace number 1440. Inset shows sample singular radar trace.

Figure 6a. Data are scattered within a maximum range of $+30 \mathrm{~cm}$ and snow depth tends to increase with elevation.

At Scott Glacier we also identified a continuous, internal reflection within the seasonal snowpack spanning the entire $1.5 \mathrm{~km}$ image. Given the ubiquitous and consistent nature of this layer, it may be a radar artifact caused by multiple radartravel paths, rather than an internal reflector. However, we provide evidence that these internal reflections (endonivean) at Scott Glacier are a real part of the snowpack stratigraphy. First, reflected signal power from the layer becomes weaker with elevation, suggesting a real, elevation-dependent density contrast that attenuates with elevation. Such a scenario could occur if an autumn rain-on-snow event had densified the near-surface snow at lower elevations. Second, the endonivean has characteristics that suggest it is related to a precipitation event (Fig. 6b). The layer below R1 $\left(h_{\mathrm{S}}-\mathrm{R} 1\right)$ increases in thickness with elevation at a greater rate than the overlying layer. This commonly occurs as the ratio of rain to snow on the glacier decreases throughout the winter. Hence, the internal reflector is likely a layer of denser snow, possibly generated by a winter melt-and-refreeze event or a rain-on-snow event, during which the saturated snow freezes and is buried by subsequent snowfall.

\section{Accumulation area of glaciers}

In the accumulation zone, the subnivean material is no longer glacier ice but firn - a polycrystalline aggregate of snow that has outlasted the previous summer. Figure $7 \mathrm{a}$ shows the appearance of the snow/firn reflector on a transverse section of Scott Glacier at $\sim 850$ ma.s.I. (Fig. 3c for location). On the left part of the image (trace number $<2450$ ), the characteristics of the image are entirely similar to those depicted in Figure 5 (snow covering glacier ice, R1 at the base of the snowpack and $R_{i}$, internal reflection). On the other side of the glacier, a second reflector is observed beneath R1 (R2, likely the interface between 2012 firn and glacier ice; Fig. 7a). In this situation, the reflections indicate a gradual transition of glacier ice into firn; thus, identification of the previous year's summer surface is possible. At higher elevation $(>1000 \mathrm{~m})$, the firn layer is still characterized by a

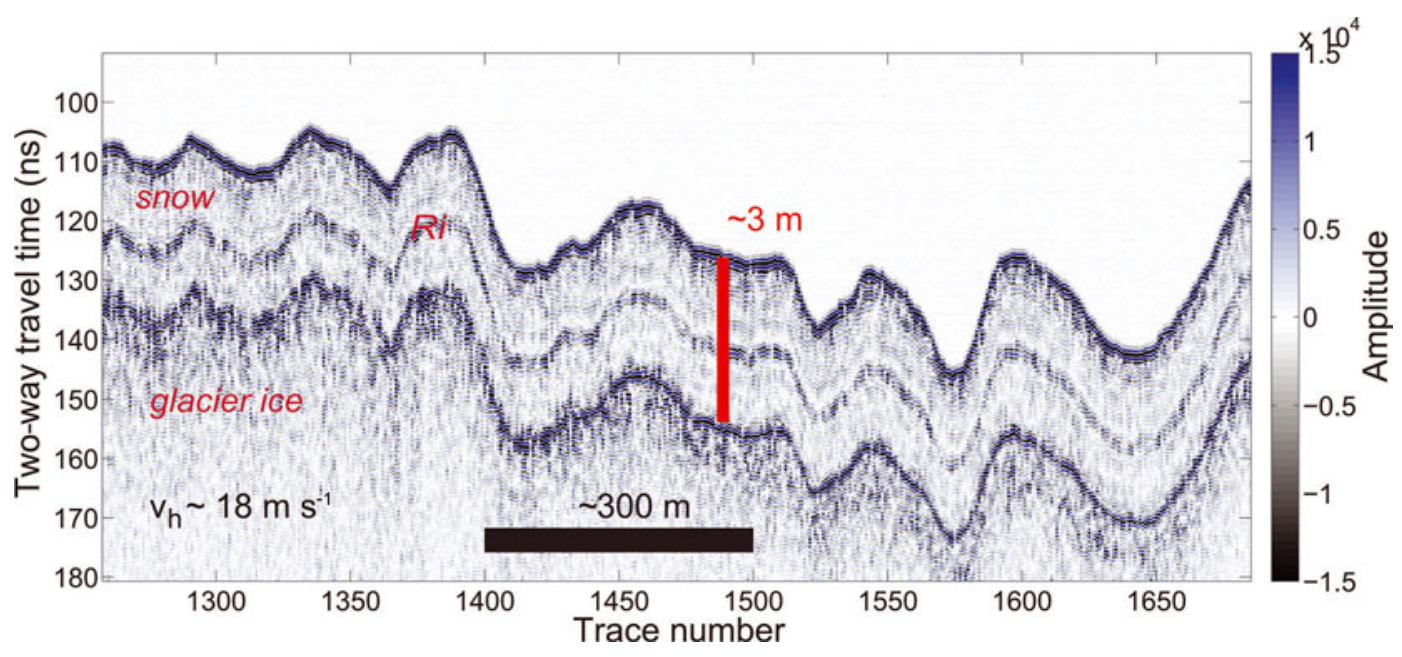

Fig. 5. $500 \mathrm{MHz}$, helicopter-borne GPR image on the ablation area of Scott Glacier, Prince William Sound (location in Fig. 3c). The snowpack imaged is maritime. Data were acquired with a measurement every $\sim 3 \mathrm{~m}$. Data clearly display a recognizable internal reflection within the snowpack. Depth scale in the snowpack is for guidance only and was derived using radar velocity of $0.23 \mathrm{~m} \mathrm{~ns}^{-1}$. $v_{\mathrm{h}}$ indicates helicopter speed. 

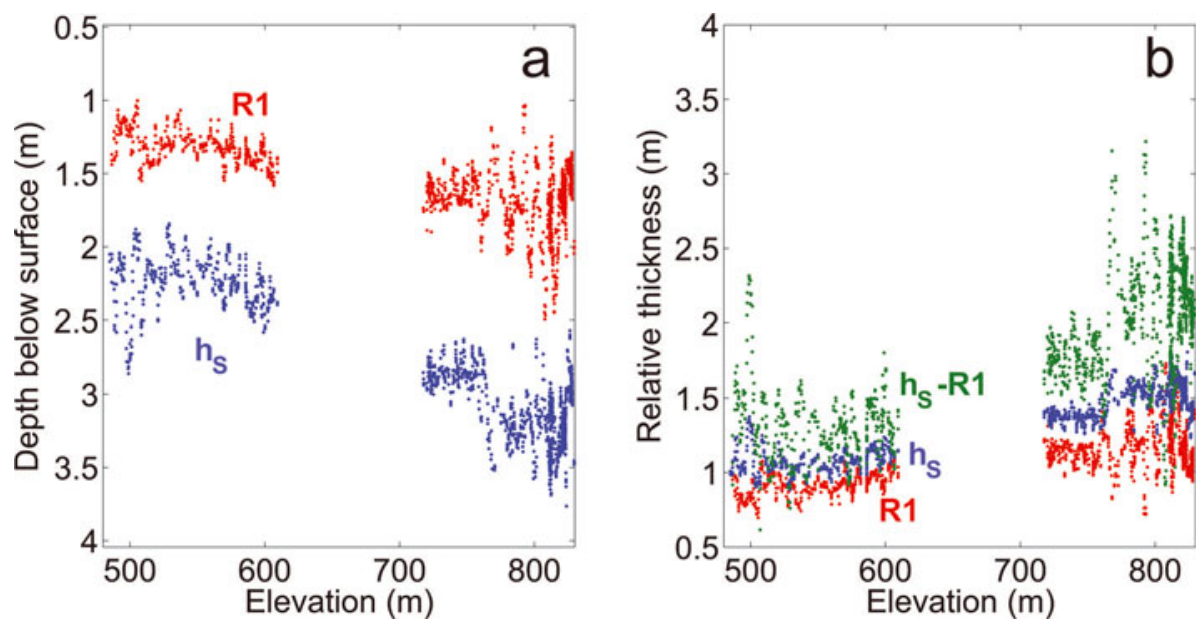

Fig. 6. Sample of seasonal ( $h_{\mathrm{S}}$, blue curve) and internal layer (R1, red curve) depth at Scott Glacier. (b) Normalized relative layer thickness (divided by layer thickness at $485 \mathrm{~m}$ ) which helps to explain how the different layers increase with elevation. The layer below R1 ( $h_{\mathrm{S}}-\mathrm{R} 1$ ), deposited earlier in the season, increases in thickness at a greater rate than the others.

noticeable increase in radar-reflected power and is readily distinguished from the seasonal snow layer (Fig. 7b). The significant density contrast between 1 -year-old firn and seasonal snow $\left(600-800 \mathrm{~kg} \mathrm{~m}^{-3}\right.$ vs $\left.300-400 \mathrm{~kg} \mathrm{~m}^{-3}\right)$ is likely the cause of the increase in radar-reflected power.

Examples from the Alaska Range do not show as clear a transition from glacier ice to firn subnivean. Figure 8a shows a $\sim 2.3 \mathrm{~km}$ long profile from the ablation area into the accumulation area of Turkey Glacier. The profile starts at an elevation of $\sim 1800 \mathrm{~m}$ and ends above $2000 \mathrm{~m}$. In the lower part of the profile, reflections from the snow/ice interface are very clear (R1) and, as in the Scott Glacier case, the reflections continue all the way up into the accumulation basin (Fig. 8a). Identification of the snow/firn interface was not always possible. Figure $8 \mathrm{~b}$ shows an area in which the GPR image gives almost no recognizable stratigraphy. Interpretation of the data becomes clear again higher on the glacier, as strata become recognizable.
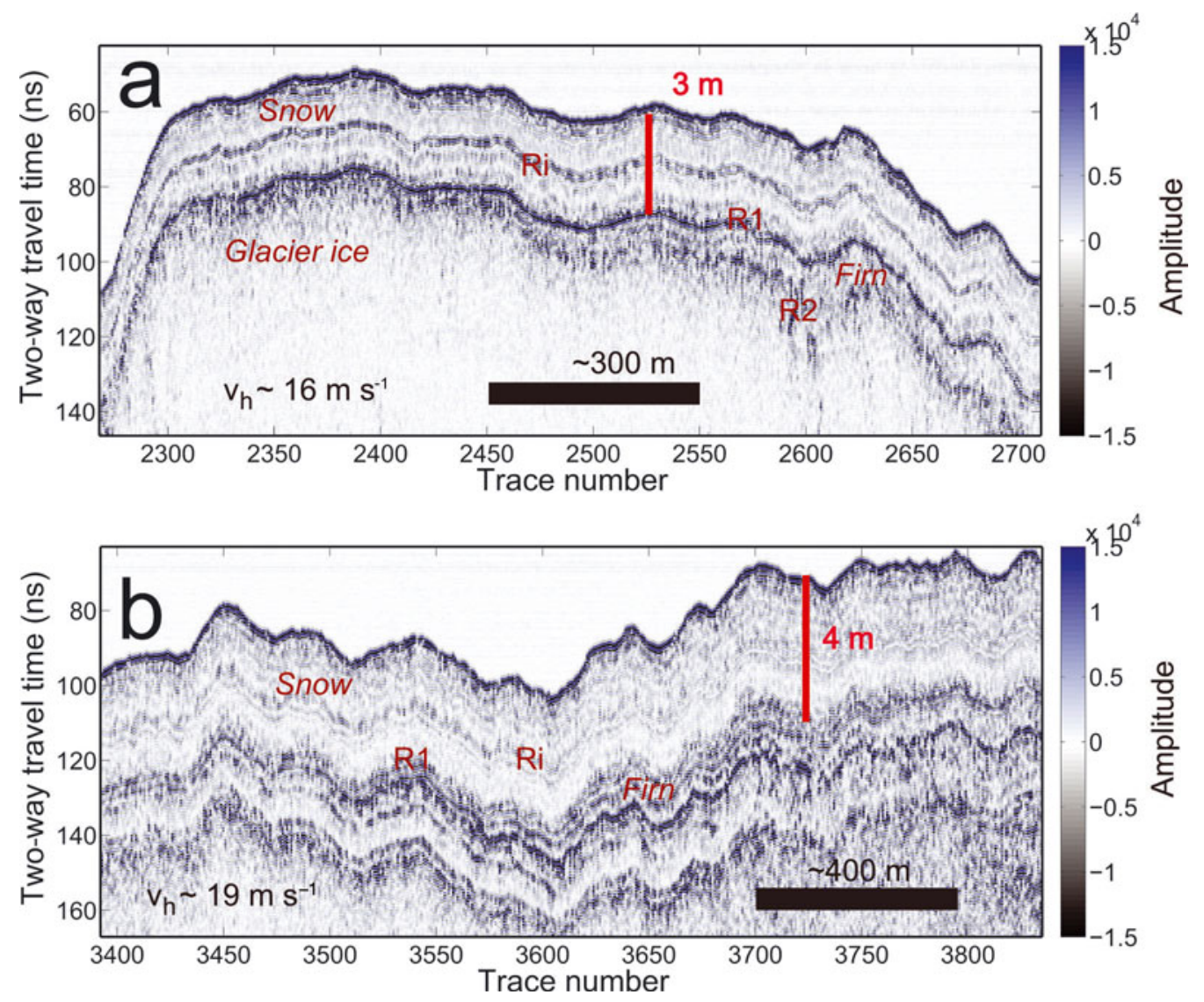

Fig. 7. $500 \mathrm{MHz}$, helicopter-borne GPR image of the accumulation area of Scott Glacier (location in Fig. 3c). (a) The transition from glacier ice to firn, imaged at 820-850 m elevation; (b) the sub-horizontal radar stratigraphy in the accumulation area, at 1020-1090 m elevation. Depth scales in the snowpack are for guidance only and were derived using radar velocity of $0.23 \mathrm{~m} \mathrm{~ns}^{-1}$. $v_{\mathrm{h}}$ indicates helicopter speed. 


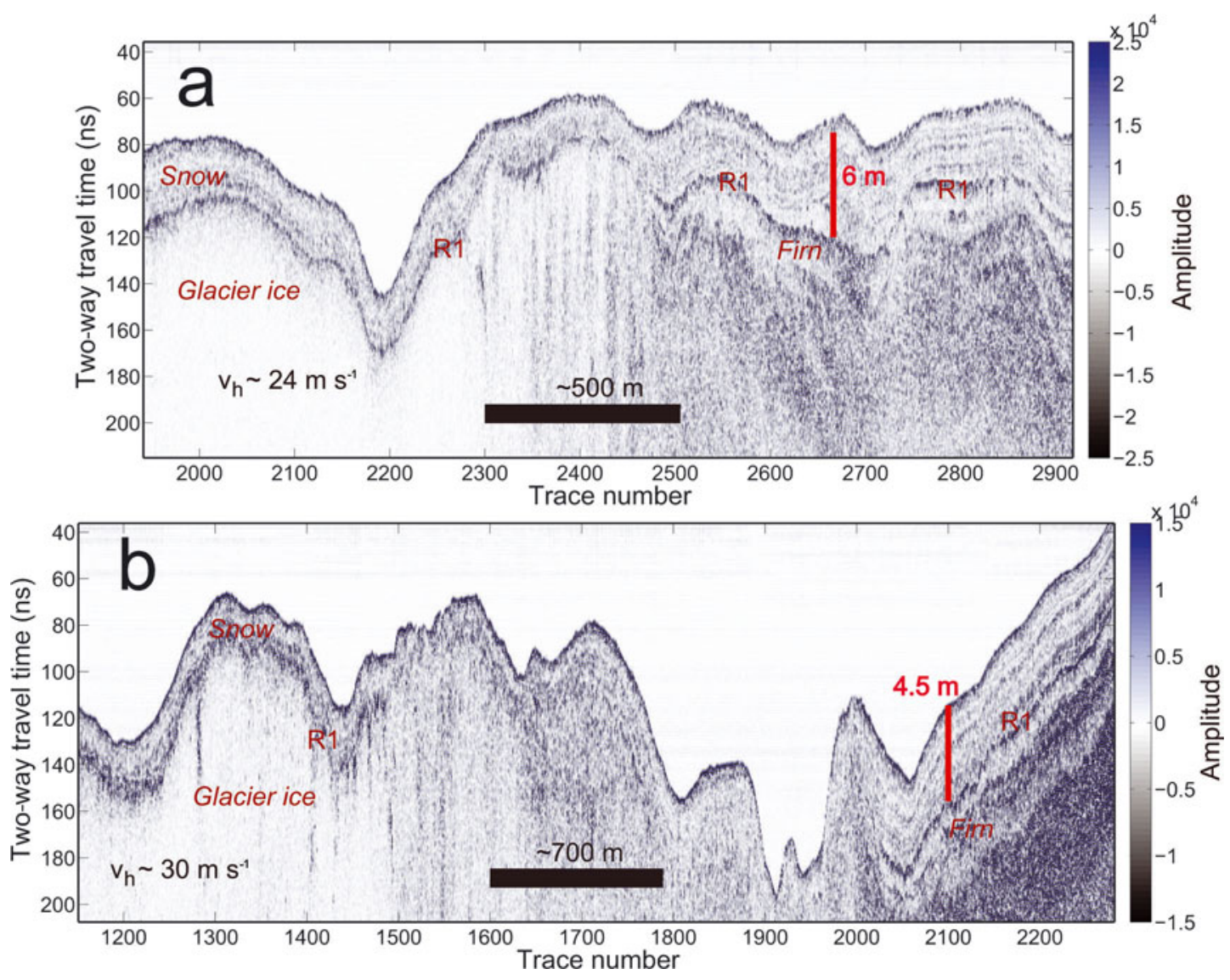

Fig. 8. $500 \mathrm{MHz}$, helicopter-borne GPR images in two different accumulation basins of West Fork Glacier (location in Fig. 3a). (a) was acquired at 1750-2070 m elevations and shows the transition from glacier ice to firn. In (b), acquired at 1850-2100 m elevation, the same transition is not as clear. Depth scales in the snowpack are for guidance only and were derived using radar velocity of $0.23 \mathrm{~m} \mathrm{~ns}^{-1}$. $v_{\mathrm{h}}$ indicates helicopter speed.

\section{Debris-covered glacier ice and medial moraines}

The terminus of Susitna Glacier (SG in Fig. 3a) is debriscovered, and looped moraines (characteristic of surge-type glaciers) dominate much of the lower ablation area. Figure 9a shows radar returns along a transect on the debris-covered terminus at an elevation of $\sim 900 \mathrm{~m}$. Ground observations at this location confirm a heterogeneous debris cover with a high degree of surface roughness at the base of the snowpack (Fig. 3a). These surface conditions, in combination with the helicopter-borne radar remote sensing employed here, make it nearly impossible to trace a continuous reflector for snow-depth estimates. However, sporadic estimates of snow thickness can be obtained in this area because the snow-ground reflector is identifiable.

At higher elevation in the ablation area, the variable configuration of the debris cover also affects the quality of the radar data. In regions of bare glacier ice we observed high-quality radar data with a recognizable and continuous series of reflections (Fig. 9b). Further up-glacier, there are large surge-type looped moraines. Figure 9c shows GPR data from this area, revealing large variability in snow thickness. Snowdrifts as thick as $3.5 \mathrm{~m}$ are present on one side of the moraine and absent on the other (Fig. 9c).

\section{Alpine tundra}

In the alpine tundra of the Alaska Range, we retrieved good radar data for snow-depth determination. Figure 10a shows a profile across a corridor of freshwater ice, at an elevation of $\sim 1000 \mathrm{~m}$, with extremely thin snow. It is possible to observe areas both with no snow and with snow $<0.3 \mathrm{~m}$. Data quality over tundra is also good at higher elevations (e.g. Fig. $10 \mathrm{~b} ; \sim 1100 \mathrm{~m}$, snow depths as great as $2 \mathrm{~m}$ ).

\section{Boreal forest}

Near the glaciers of the Susitna basin, we had the opportunity to collect data over the boreal forest. The main question we had when surveying this kind of terrain was whether the canopy cover would interfere with our retrieval of snow depth. Results show that the radar pulse travels through the canopy cover, and indeed subsequently penetrates the snowpack. Reflections off the canopy cover are generally weak and only appear in radar images if relative amplitudes are enhanced during data processing (Fig. 11). A visualization of radar images with a focus on the snow cover shows that both $t_{\mathrm{i}}$ and $t_{\mathrm{s}}$ are clearly definable, and the presence of trees does not significantly affect snow-depth retrieval.

Off-ice data in the boreal forest show another compelling potential of helicopter-borne $500 \mathrm{MHz}$ GPR surveying (Fig. 10). The radar images in Figure 11 show variable tree coverage and canopy height (e.g. trees in Fig. 10 are $15 \mathrm{~m}$ tall, while trees in Fig. 11 are $\sim 6 \mathrm{~m}$ tall). Additionally, we noticed a variable intensity of reflections at the base of the snow (see bright reflections in Fig. 12). These bright zones probably correspond to freshwater ice in depressions, which is clearly visible on the radar images, where the reflection from the base of the snowpack is followed by a reflection from the base of the freshwater ice. 

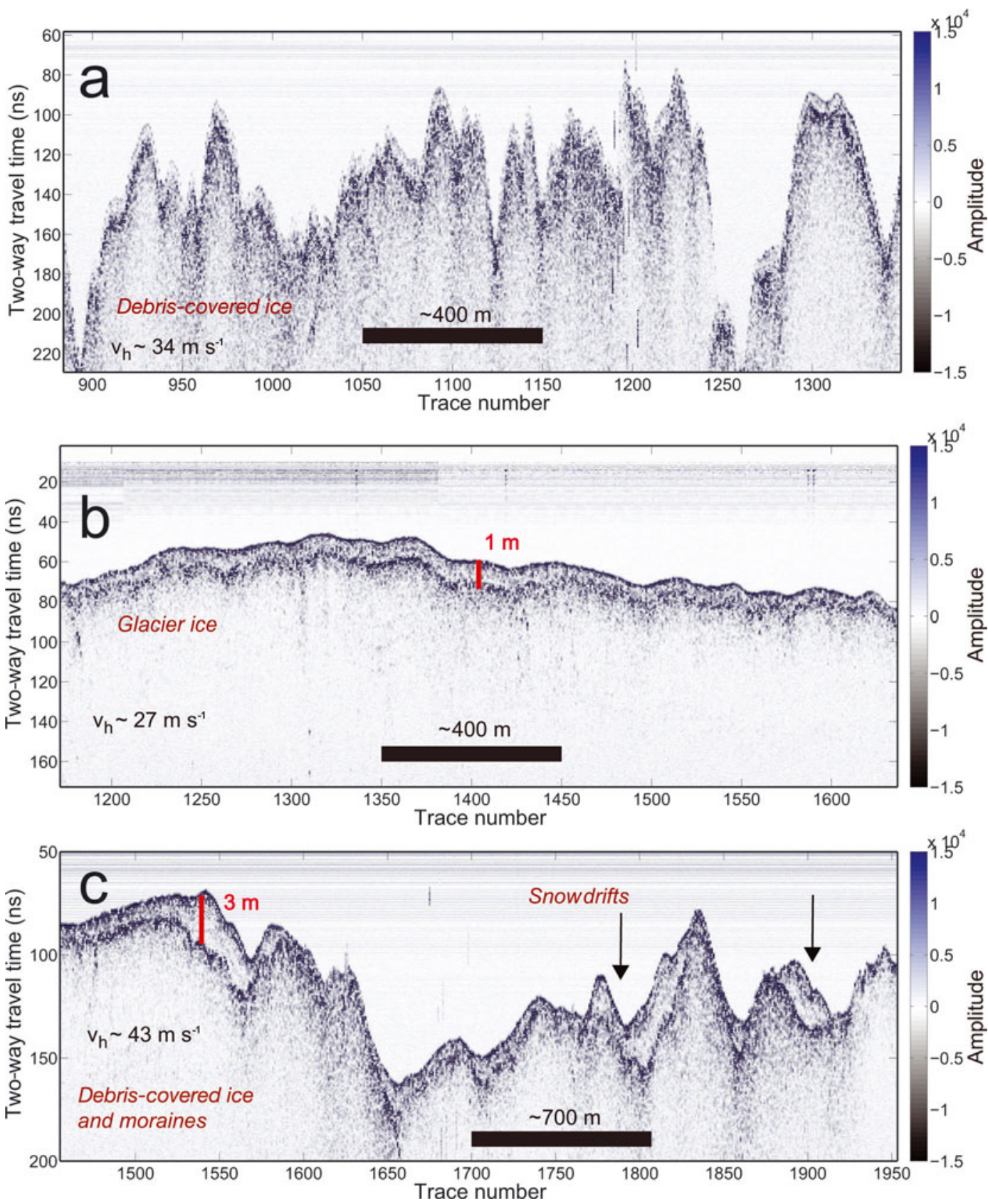

Fig. 9. $500 \mathrm{MHz}$, helicopter-borne GPR images on debris-covered Susitna Glacier in the Alaska Range (location in Fig. 3a). (a) shows the terminus at the lower area (900-950 m), (b) is at 1000-1200 m and (c) is at 1300-1350 m, in an area with large moraines. Depth scales in the snowpack are for guidance only and were derived using radar velocity of $0.23 \mathrm{~m} \mathrm{~ns}^{-1} . v_{\mathrm{h}}$ indicates helicopter speed.

\section{DISCUSSION}

\section{Uncertainties in snow depth and snow water equivalent determination}

This paper focuses on the interpretation of radar imaging of end-of-winter snowpack over multiple glacier and land surface types in mountainous areas of central and southcentral Alaska using a commercially available GPR. While it is beyond the scope of this investigation to present glacieror catchment-wide snow depth and snow water equivalent (SWE) estimates, we do include an estimated snow depth in our plots in order to show the potential of these radargrams. Here we also assess the uncertainties in our snow depth estimates.

The uncertainties in $h_{\mathrm{S}}$ estimates can be derived from uncertainties in $t_{\mathrm{S}}$ and $v_{\mathrm{S}}$. Using formal error propagation
(Topping, 1972) the uncertainty in snow depth $\delta_{h_{\mathrm{S}}}$ is given by

$$
\delta_{h_{\mathrm{S}}}=\sqrt{t_{\mathrm{S}}^{2} \delta_{v_{\mathrm{S}}}^{2}+v_{\mathrm{S}}^{2} \delta_{t_{\mathrm{S}}}^{2}}
$$

where $\delta_{t_{\mathrm{s}}}$ is given by

$$
\delta_{t_{\mathrm{S}}}=0.5 \sqrt{\delta_{t_{\mathrm{i}}}^{2}+\delta_{t_{\mathrm{a}}}^{2}}
$$

we consider $\delta_{t_{\mathrm{i}}}=\delta_{t_{\mathrm{a}}}=0.1 \mathrm{~ns}$ (twice the temporal sampling rate of the system) and $\delta_{v_{\mathrm{S}}}=0.01 \mathrm{mns}^{-1}$ and we obtain $\delta_{h_{\mathrm{s}}}=9 \%$. Note that this is an uncertainty associated with a single observation (not applicable across the entire glacier).

GPR estimates of $h_{\mathrm{S}}$ in a dry snowpack are directly convertible in SWE, because they rely on $v_{S}$, a direct function of snow density. In this particular study, we have assumed snow density to derive $v_{\mathrm{S}}$, hence, the same snow 


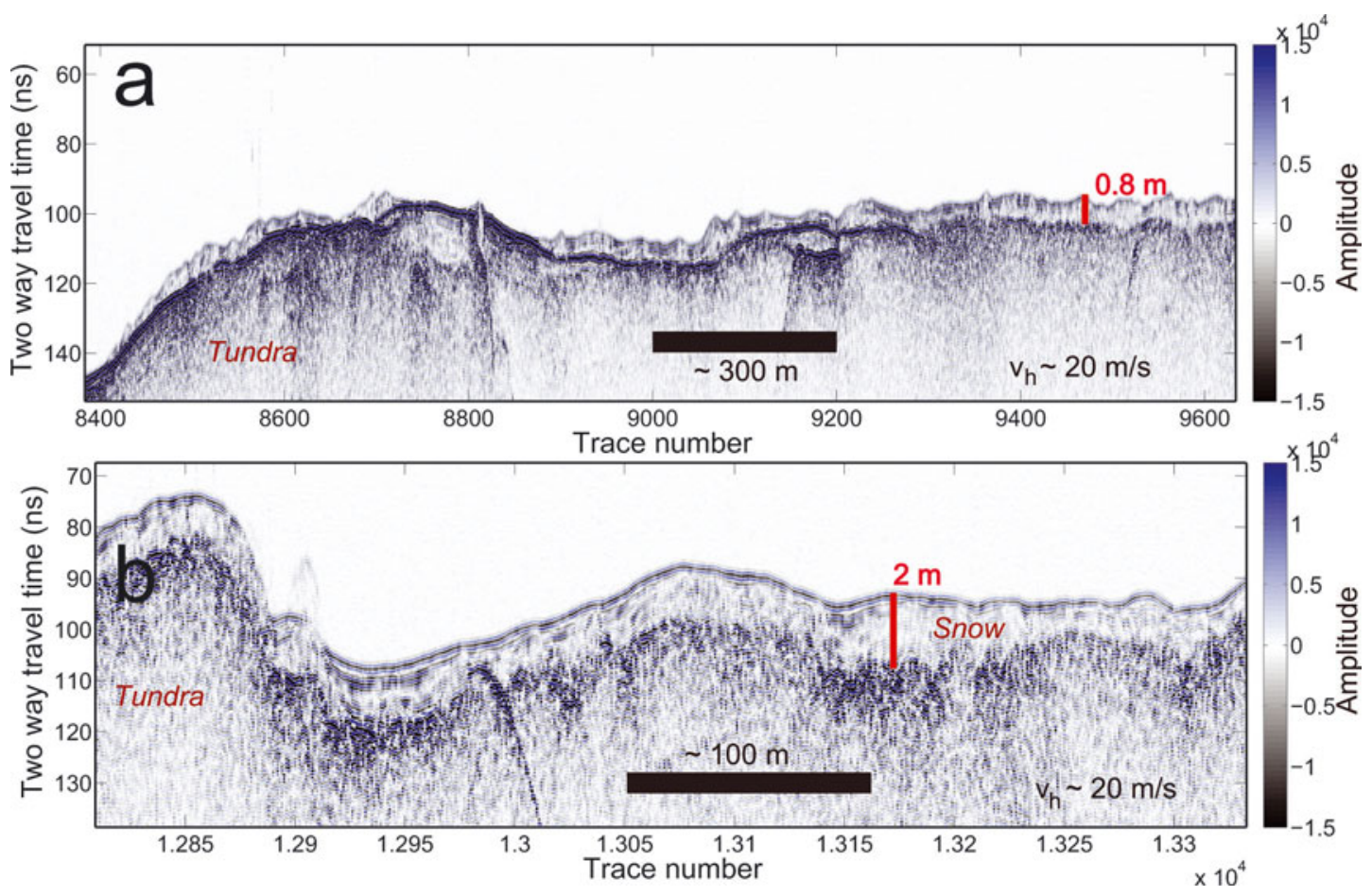

Fig. 10. $500 \mathrm{MHz}$, helicopter-borne GPR image acquired in mountainous tundra terrain in the Alaska Range (location in Fig. $3 \mathrm{~b}$ ). $v_{\mathrm{h}}$ indicates helicopter speed.

density can be used to translate $h_{\mathrm{S}}$ into SWE values and associated uncertainties.

In addition to the uncertainties in $h_{\mathrm{S}}$, it is important to consider the minimum thickness that we can resolve with the radar system. The geophysical problem of wave propagation in our survey is analogous to a two-layer case in seismic imaging. In this situation, the minimum resolvable thickness is normally approximated to onequarter of the wavelength (e.g. Sheriff and Geldart, 1999). Using radar wave velocity of $0.23 \mathrm{~m} \mathrm{~ns}^{-1}$ we obtain a wavelength of $46 \mathrm{~cm}$, yielding minimum resolvable thickness of $\sim 11 \mathrm{~cm}$.
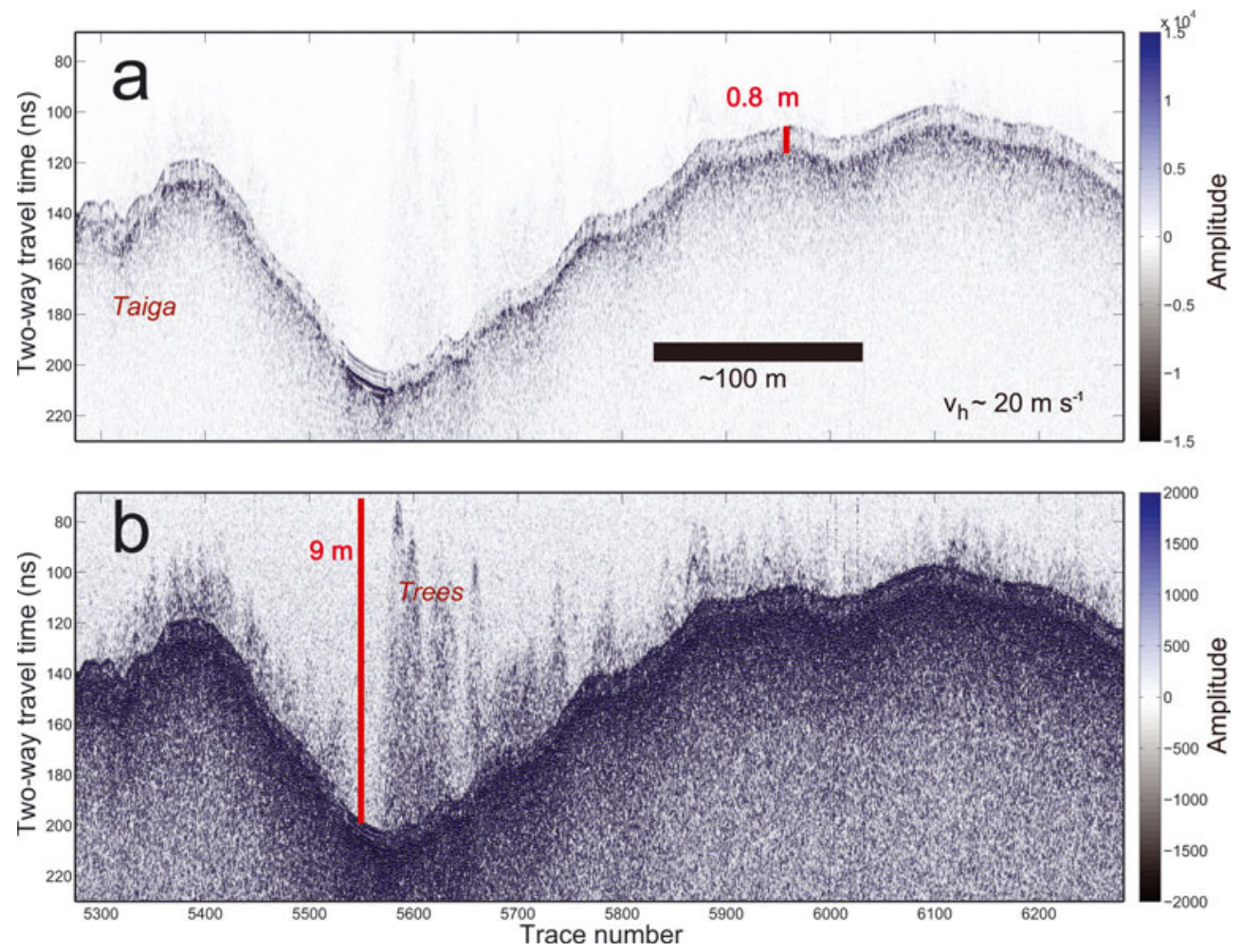

Fig. 11. $500 \mathrm{MHz}$, helicopter-borne GPR image acquired over the boreal forest in the Susitna valley in the Alaska Range (location in Fig. 3b). (a) shows the snow-ground reflector, whereas in (b) the color amplitude scale is modified to highlight returns from the canopy cover. Depth scales in snow and air were derived using radar velocities of 0.23 and $0.3 \mathrm{~m} \mathrm{~ns}^{-1}$, respectively. $v_{\mathrm{h}}$ indicates helicopter speed. 

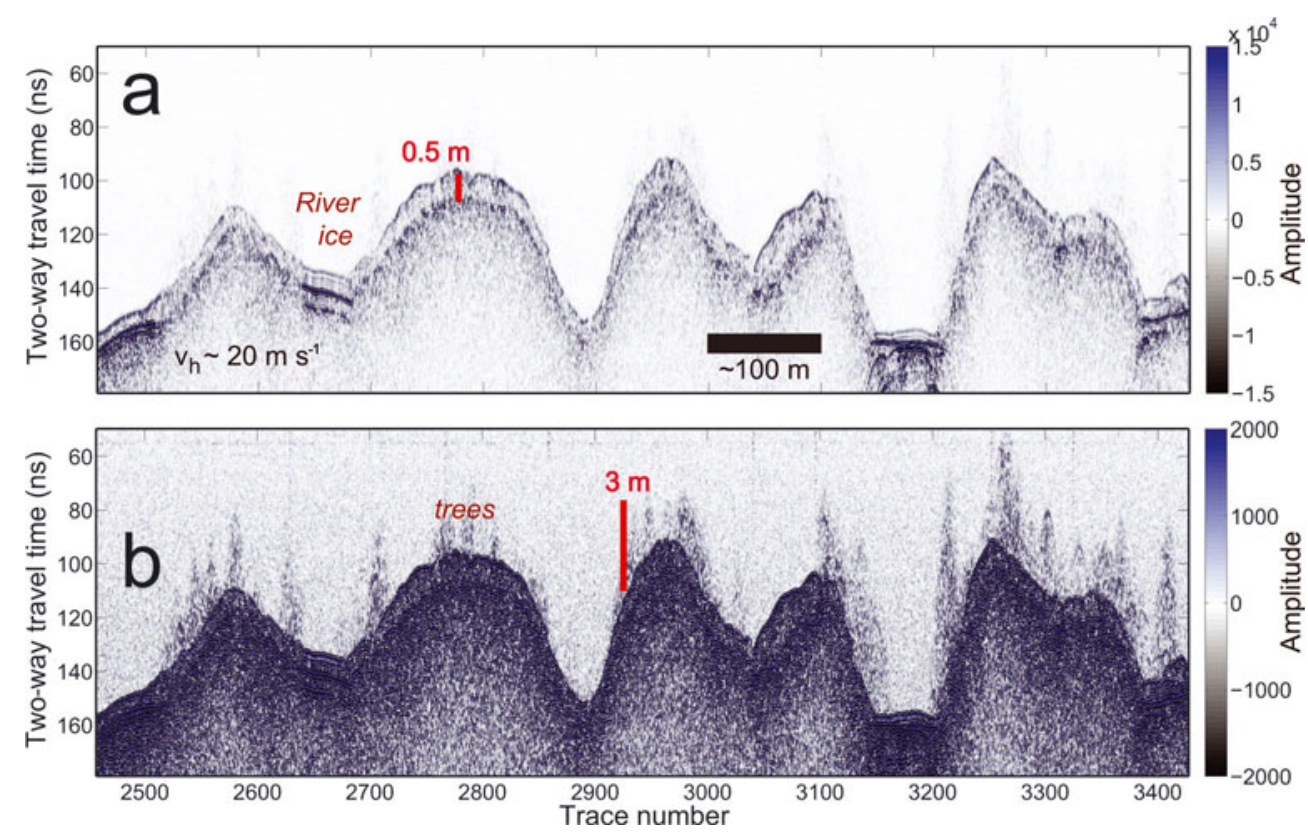

Fig. 12. Same as Figure 11, showing the presence of variable freshwater ice conditions.

\section{The problem of liquid water in the snowpack}

The presence of liquid water in the snowpack presents a significant problem in GPR surveys of snow depth and snow water equivalence. Bradford and others (2009), working on snow in the pendular regime (water content $<10-15 \%$ ), determined both snow density and liquid water content with a ground-based GPR by utilizing multi-offset data to continuously measure velocity and signal attenuation. For higher snow water content (funicular regime, $>15 \%$ ) the GPR signal undergoes strong attenuation. Gusmeroli and Grosse (2012) suggested that water content $>30 \%$ attenuates the radar signal so strongly that data from lake-ice thickness surveys in wet snow conditions are completely unreliable. While the methodology proposed by Bradford and others (2009) appears promising, it requires the use of multiple transducers to acquire multi-offset data, a complicated component array that does not easily integrate with typical contract aircraft used for airborne surveys. Thus, it is critical to perform GPR surveys of snow depth prior to melt onset.

\section{Radar imaging at different flying speeds}

In the previous subsections we have shown that generally, over the mountainous terrains of Alaska, helicopter-borne radar imaging of snow cover can be successful. Here we investigate the question, what is the optimal balance between data retrieval and flying speed? Most of the data presented in this paper were collected at flying speeds of $\sim 15-20 \mathrm{~m} \mathrm{~s}^{-1}$ (30-40 kt). These flying speeds are higher than normally reported for helicopter-borne GPR snow survey over glaciers (Machguth and others (2006) report data collection at $6 \mathrm{~m} \mathrm{~s}^{-1}$ ). In our experiments we also tested the possibility of acquiring data at much higher flying speeds. At West Fork Glacier, for example, we varied flying speed from a minimum of $10 \mathrm{~m} \mathrm{~s}^{-1}$ to a maximum of $45 \mathrm{~m} \mathrm{~s}^{-1}$ (Fig. 13a and b). Higher flying speeds corresponded to significantly coarser data resolution. Flying at $10 \mathrm{~m} \mathrm{~s}^{-1}$, we acquired data at a rate of 0.8 traces $\mathrm{m}^{-1}$, whereas at $45 \mathrm{~m} \mathrm{~s}^{-1}$ flying speed we acquired data at $\sim 0.2$ traces $\mathrm{m}^{-1}$ (Fig. 13b). The corresponding radar images display this seemingly drastic difference.
Figure 13 shows a comparison between similar $1 \mathrm{~km}$ long radar images acquired at different speeds. The difference in the quality of radar data is evident. The $10 \mathrm{~m} \mathrm{~s}^{-1}$ acquisitions show a clear, detailed series of echoes from the base of the snow not quite observable in the $40 \mathrm{~m} \mathrm{~s}^{-1}$ image. Nonetheless, while much detail is lost, it is still possible to obtain a general picture of snow depth in the area. While highspeed flying does provide some snow-depth information over glaciers, it is not successful on rougher tundra terrains. Figure 14 shows a radar image acquired at $\sim 45 \mathrm{~m} \mathrm{~s}^{-1}$ flying speed (87 kt) over mountain tundra in the Alaska Range. At these high flying speeds, data quality is low, and reflections from the base of the snowpack are no longer recognizable. While it is possible to obtain good data at $20 \mathrm{~m} \mathrm{~s}^{-1}$, doubling this speed may drastically reduce data quality.

\section{CONCLUSIONS AND OUTLOOK}

We have presented numerous $500 \mathrm{MHz}$ GPR images of the snowpack on and around glaciers in Alaska. We retrieved good data for glaciers, taiga, and tundra land covers. The technique we tested works very well in zones of smooth topography, where reflections from the base of the snowpack are clearly recognizable. Radar returns are difficult to interpret in regions of rough topography (debris-covered termini and icefalls).

Helicopter-borne GPR surveys appear useful for understanding details of snow and firn facies in accumulation zones of maritime and continental glaciers. Preliminary results show the presence of internal layering within a maritime glacier in Prince William Sound, details not present in the continental, high-altitude snowpack of the Alaska Range (Figs 4 and 5). There are also differences between maritime and continental glaciers in the accumulation areas. In particular, the identification of the snow/firn boundary appeared to be clearer in maritime zones (Figs 6 and 7). This may be because layers caused by the refreezing of wet snow are more likely in maritime glaciers, though this remains a topic for future investigations. In debris-covered zones, we failed to consistently image the snowpack, whereas we 


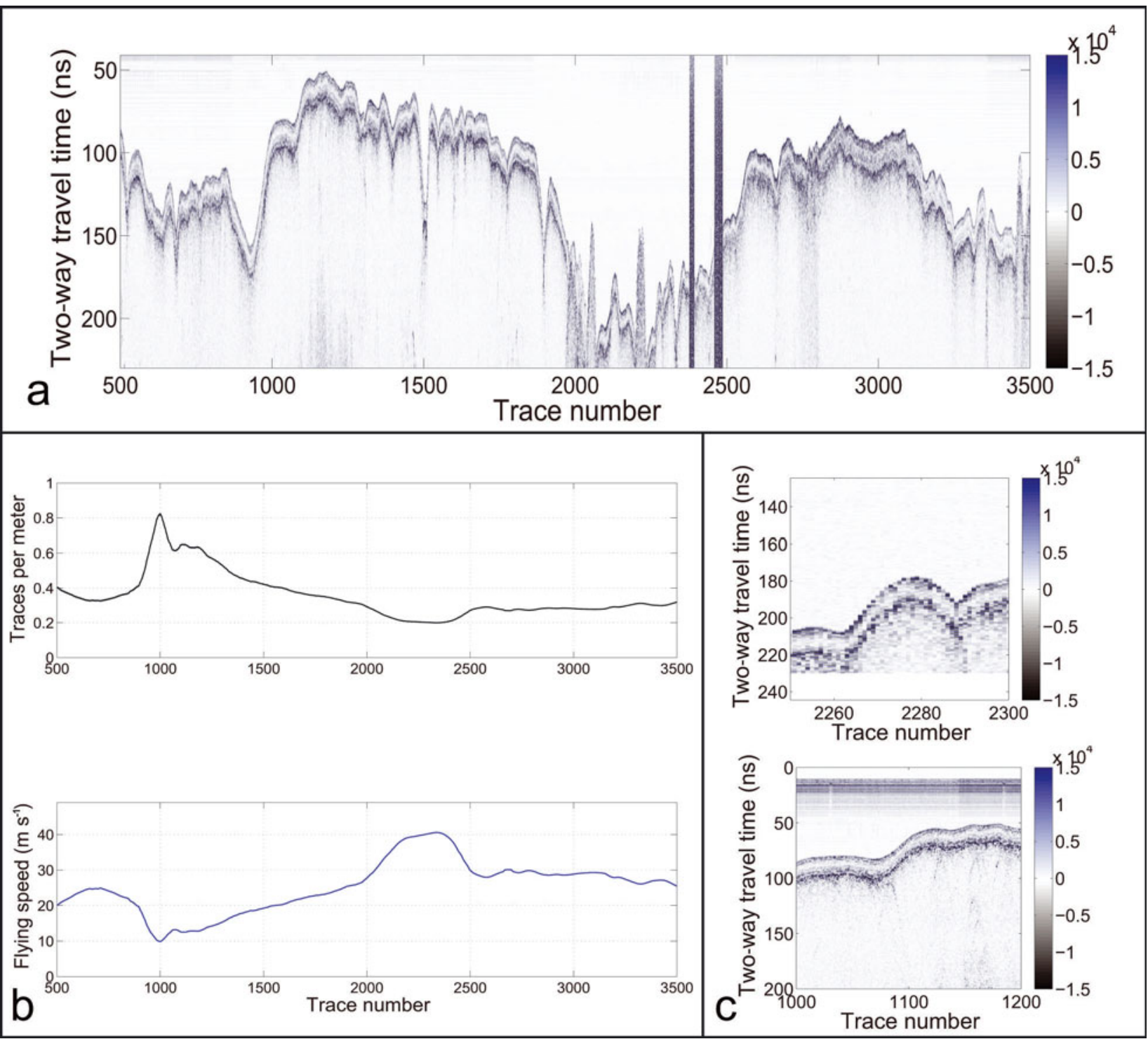

Fig. 13. Effects of flying speed on the quality of GPR images at West Fork Glacier. (a) A full radar image acquired at variable speed. (b) Spatial coverage of the profile; the upper panel shows measurements per meter while the lower panel shows the flying speed. (c) Data quality for different flying speeds. The upper panel is a $\sim 1000 \mathrm{~m}$ radar image acquired at a speed of $40 \mathrm{~m} \mathrm{~s}^{-1}\left(0.2 \operatorname{traces~}^{-1}\right)$. The lower panel shows a $\sim 250 \mathrm{~m}$ long transect acquired at a speed of $10 \mathrm{~m} \mathrm{~s}^{-1}\left(0.8\right.$ traces $\left.\mathrm{m}^{-1}\right)$. While data quality is clearly affected by changing speed, we can still retrieve snow depth at $40 \mathrm{~m} \mathrm{~s}^{-1}$.

succeeded in imaging deep snowdrifts formed on the lee of medial moraines. Surveys were also successful on forested taiga, as the signal penetrated through the canopy.

Our future studies will focus on understanding the differences in radar stratigraphy in the accumulation areas of continental and maritime glaciers, as well as analyzing common-midpoint data to determine the correct radar velocity for use in our time-depth conversions. These efforts will ultimately lead to new datasets for snow accumulation in Alaska, which are necessary for estimating glacier changes, forecasting freshwater delivery to riverine and marine ecosystems, improving flood forecasting and modeling elastic changes in the Earth's crust.

\section{ACKNOWLEDGEMENTS}

The project described in this publication was funded by the Climate and Cryosphere Hazards Program at the Alaska Division of Geological \& Geophysical Surveys through a

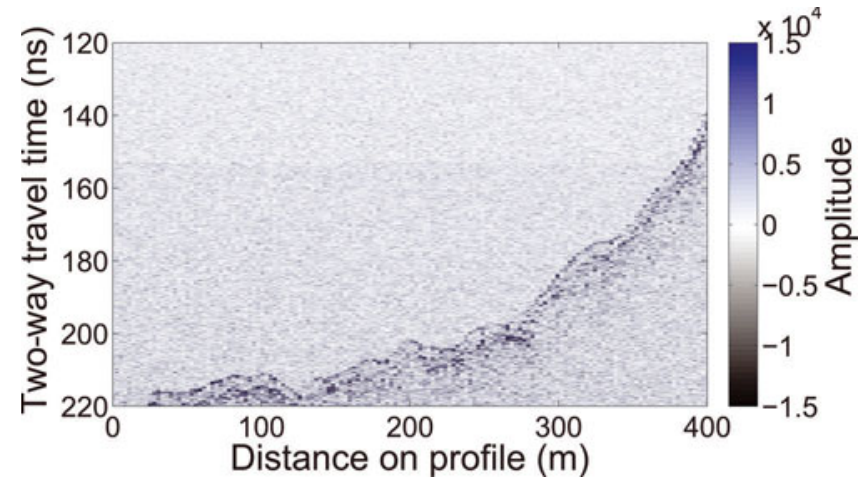

Fig. 14. $500 \mathrm{MHz}$, helicopter-borne GPR image acquired in mountainous tundra terrains in the Alaska Range. The helicopter flying speed was $\sim 45 \mathrm{~m} \mathrm{~s}^{-1}$ (more than twice the average speed used in our survey and $\sim 7$ times faster than previously reported in the literature). At such a high speed, data quality is very low and the reflections from the base of the snowpack are no longer recognizable. 
Capital Improvement Project award; the Alaska Climate Science Center, funded by Cooperative Agreement No. G10AC00588 from the United States Geological Survey and the Oil Spills Recovery Institute grant OS-12-10; and NASA's Cryosphere Sciences Program (grant NNX12AK37G). The contents of the paper are solely the responsibility of the authors and do not necessarily represent the official views of funding agencies. None of the science published in this study would have been possible without the skills of Garth Murdock and Martin Hoessinger, our pilots, who literally collected the data while we sat in the helicopter cabin, enjoying the view and/or the radar screen. A.G. thanks Larry Hinzman and Scott Rupp for encouragement and support, as well as Matthew Sturm for countless discussions. Skye Sturm graciously offered her time and talent in editing the manuscript and preparing Figure 1. Justin Rich prepared the maps in Figures 2 and 3 and Nate Bauer provided useful edits.

\section{REFERENCES}

Arcone SA (2002) Airborne-radar stratigraphy and electrical structure of temperate firn: Bagley Ice Field, Alaska, U.S.A. J. Glaciol., 48(161), 317-334 (doi: 10.3189/172756502781831412)

Arcone SA and Yankielun NE (2000) 1.4 GHz radar penetration and evidence of drainage structures in temperate ice: Black Rapids Glacier, Alaska, U.S.A. J. Glaciol., 46(154), 477-490 (doi: 10.3189/172756500781833133)

Booth AD, Mercer A, Clark R, Murray T, Jansson P and Axtell C (2013) A comparison of seismic and radar methods to establish the thickness and density of glacier snow cover. Ann. Glaciol., 54(64), 73-82 (doi: 10.3189/2013AoG64A044)

Bradford JH, Harper JT and Brown J (2009) Complex dielectric permittivity measurements from ground-penetrating radar data to estimate snow liquid water content in the pendular regime. Water Resour. Res., 45(8), W08403 (doi: 10.1029/ 2008WR007341)

Brown J, Bradford JH, Harper J, Pfeffer WT, Humphrey NF and Mosley-Thompson ES (2012) Georadar-derived estimates of firn density in the percolation zone, western Greenland ice sheet. J. Geophys. Res., 117(F1), F01011 (doi: 10.1029/2011JF002089)

Daniels DJ (2004) Ground penetrating radar, 2nd edn. Institution of Electrical Engineers, London

Gusmeroli A and Grosse G (2012) Ground penetrating radar detection of subsnow slush on ice-covered lakes in interior Alaska. Cryosphere, 6(6), 1435-1443 (doi: 10.5194/tc-6-14352012)

Gusmeroli A, Jansson P, Pettersson R and Murray T (2012) Twenty years of cold surface layer thinning at Storglaciären, sub-Arctic Sweden, 1989-2009. J. Glaciol., 58(207), 3-10 (doi: 10.3189/ 2012JoG11J018)

Gusmeroli A, Arendt A, Atwood D, Kampes B, Sanford M and Young JC (2013) Variable penetration depth of interferometric synthetic aperture radar signals in Alaska glaciers: a cold surface layer hypothesis. Ann. Glaciol., 54(64), 218-223 (doi: 10.3189/ 2013AoG64A114)

Holmgren J, Sturm M, Yankielun NE and Koh G (1998) Extensive measurements of snow depth using FM-CW radar. Cold Reg. Sci. Technol., 27(1), 17-30 (doi: 10.1016/S0165-232X(97) 00020-7)

Kovacs A, Gow AJ and Morey RM (1995) The in-situ dielectric constant of polar firn revisited. Cold Reg. Sci. Technol., 23(3), 245-256 (doi: 10.1016/0165-232X(94)00016-Q)

Liu $Y$ and 6 others (2014) Assimilating satellite-based snow depth and snow cover products for improving snow predictions in Alaska. Adv. Water Resour., 54, 208-227 (doi: 10.1016/ j.advwatres.2013.02.005)

Machguth H, Eisen O, Paul F and Hoelzle M (2006) Strong spatial variability of snow accumulation observed with helicopterborne GPR on two adjacent Alpine glaciers. Geophys. Res. Lett., 33(13), L13503 (doi: 10.1029/2006GL026576)

Marchand W-D, Killingtveit $\AA$, Wilén P and Wikström P (2003) Comparison of ground-based and airborne snow depth measurements with georadar systems, case study. Nord. Hydrol., 34(5), 427-448 (doi: 10.2166/nh.2003.025)

Marshall HP, Birkeland K, Elder K and Meiners T (2008) Helicopterbased microwave radar measurements in alpine terrain. In Campbell C, Conger S and Haegeli $\mathrm{P}$ eds. Proceedings of the International Snow Science Workshop, 21-27 September 2008, Whistler, British Columbia, Canada. International Snow Science Workshop, Whistler, BC

Mayo LR, Trabant DC and March RS (2004) A 30-year record of surface mass balance (1966-95) and motion and surface altitude (1975-95) at Wolverine Glacier, Alaska. USGS Open File Rep. 2004-1069.

Panzer B and 8 others (2013) An ultra-wideband, microwave radar for measuring snow thickness on sea ice and mapping nearsurface internal layers in polar firn. J. Glaciol., 59(214), 244-254 (doi: 10.3189/2013JoG12J128)

Ryser C, Lüthi M, Blindow N, Suckro S, Funk M and Bauder A (2013) Cold ice in the ablation zone: its relation to glacier hydrology and ice water content. J. Geophys. Res. Earth Surf., 118(2), 693-705 (doi: 10.1029/2012JF002526)

Sheriff RE and Geldart LP (1999) Exploration seismology. Cambridge University Press, Cambridge

Tiuri MT, Sihvola AH, Nyfors EG and Hallikainen MT (1984) The complex dielectric constant of snow at microwave frequencies. IEEE J. Ocean. Eng., 9(5), 377-382 (doi: 10.1109/ JOE.1984.1145645)

Topping J (1972) Errors of observation and their treatment. Chapman and Hall, London

Venier GO and Cross FR (1972) An experimental look at the use of radar to measure snow and ice depths. (CRC Technical Note 646) Communications Research Center, Ottawa

Yankielun N, Rosenthal W and Davis RE (2004) Alpine snow depth measurements from aerial FMCW radar. Cold Reg. Sci. Technol., 40(1-2), 123-134 (doi: 10.1016/j.coldregions.2004.06.005) 